\title{
THE BUDGET BUREAU THAT WAS: THOUGHTS ON THE RISE, DECLINE, AND FUTURE OF A PRESIDENTIAL AGENCY
}

\author{
ArLEN SCHICK*
}

On July I, I970, during its fiftieth year, the United States Bureau of the Budget nominally ceased to exist. Its function, personnel, and traditions were transferred to the Office of Management and Budget, a new unit within the Executive Office of the President with a potentially broader mission than its predecessor carried. ${ }^{1}$ From the point of view of bureaucratic continuity, the line of authority established in the Budget and Accounting Act of I92I has been perpetuated. But on the premise that organizations ordinarily are restructured only after they have declined, not at the peak of their capabilities, this article discusses the inadequacies which led to the decease of the Bureau, once the premier institution in the President's Office. And on the presumption that reorganizations rarely work out exactly as intended, we will examine the prospects for the Office of Management and Budget.

It is difficult to make a case that the Bureau was inadequate for its various roles, for it always was graced with a favorable public image. Periodically, the Bureau was featured in the media as a valiant guardian of the purse, its directors as embattled enemies of spend-lust bureaucrats, its examiners as men working without honor or acclaim to combat the predatory wiles of federal agencies. The Bureau's image was enhanced by the absence of serious scandal or impropriety; even when there were visible shortcomings in the budget process (such as the gross underestimation of the costs of the Vietnam War and the miscalculation of the 197I budget deficit), the Bureau managed to escape severe opprobrium. This sheltered existence was due in good part to the Bureau's presidential mission and cloistered mode of operation. Only a portion of the Bureau's reality was open to public view, and in a town that often seems to thrive on a fishbowl existence, the Bureau was spared close scrutiny. Few leaks emanated from the Bureau and not many newsmen or scholars penetrated its curtain of secrecy and bureaucratic routines. Most journal articles relate to the directorship of Harold Smith (I939-I945), a period during which the Bureau became the central management arm of the federal government. ${ }^{2}$ There is almost nothing in the public record concerning the opera-

* The Brookings Institution.

1 Technically, the functions of the Bureau of the Budget were transferred to the President, who by Executive Order, delegated them to the Office of Management and Budget. Exec. Order No. II,54I, 3 C.F.R. 10,737 (Supp. I970). It is anticipated that in the future certain administrative duties will be transferred to other federal agencies.

${ }^{3}$ See Pearson, The Budget Bureau: From Routine Business to General Staf, 3 Pub. Ad. Rev. I26 (1943); Marx, The Bureau of the Budget: Its Evolution and Présent Role, 34 AMr. PoL. Scr. Rev. 653, 869 (1945). 
tions of the Bureau during the I960's, a decade of unheralded but significant changes in the relations between the Bureau and the White House.

Nevertheless, there have been signs of a decline in the stature, if not the performance, of the Budget Bureau. Just as its location in the Executive Office Building, situated next door to the White House, once was an indication of the Bureau's eminence as a presidential institution, the recent removal of major portions of the Bureau to a less prestigious address signalled its decline relative to other presidential staffs. On certain matters, such as program planning and administrative reorganization, the Bureau's role has been subordinated, with White House aides and task forces taking the lion's share of the action. The attempt in the mid-Ig6o's to establish a Planning-Programming-Budget System manifested a conviction among top Bureau officials that the existing budgetary practices were inadequate, but the only limited application of PPBS bespoke the inability of the Bureau to significantly overhaul its own or the bureaucracy's budget traditions. In 1967 , a presidential task force found grave defects in the central administrative apparatus, and it proposed the bolstering of the Bureau's program development capabilities and the creation of a separate White House unit to coordinate federal programs. ${ }^{3}$ In the same year, the Bureau undertook an evaluation of its operations, and some changes were made in its internal structure. ${ }^{4}$ Finally, in 1970 , the President's Advisory Council on Executive Organization proposed and the President implemented the establishment of a new Domestic Council and the conversion of the Bureau into the Office of Management and Budget.

All these developments point to, but do not prove, a slippage in the perceived ability of the Bureau to discharge the functions it had acquired over the past half century. Of course, the decline of the Bureau may be a case in which expectations and demands-both of which climbed sharply in the 1960 's-rose faster than performance, rather than an outright drop in competence. Yet perceptions of inadequacy can be every bit as damaging as objective measures of performance. Furthermore, the inadequacy of the Bureau must be seen in terms of its presidential mission. Perhaps the Bureau merited its reputation as the best-informed institution in Washington, and one indispensable to the President, but this does not mean that in terms of presidential requirements it was good enough or as good as it once had been. Finally, the reader will be misguided if he interprets "inadequate" to mean "unsuccessful." By most measures, the Bureau continued to be successful in its last years. Whether or not it was adequate is the concern of this article.

\footnotetext{
${ }^{8}$ The recommendations of the Heineman Task Force (named after its chairman, Ben Heineman) have never been made public, and no action was taken on them by President Johnson.

- See United States Bureau of the Budget, The Work of the Steering Group on Evaluation of the Buresu of the Budget, A Staff Summary (1967) [hereinafter cited as Steerung Group].
} 
The Uses of the Budget Buread

During its existence, the Bureau was successful when it possessed a near monopoly in the exercise of a particular function deemed vital to presidential interests. This condition prevailed during the early years of the Bureau when it served as an instrument of presidential control over agency spending, and during later periods when the Bureau gained pre-eminence in administrative management and legislative clearance. In recent times, however, the Bureau lost its role as a unique supplier of presidential services and its functions no longer were as germane to the President as they once had been. To understand why and in what sense the Bureau was eclipsed, it is necessary to look at its several major functions in terms of their utility to the President and the position of the Bureau vis-à-vis other performers of the same functions. This rise and decline of the Bureau pertains to the three key roles it has played: central control of federal spending, leadership in administrative management, and program planning for the President. In terms of all three of these functions, the Bureau was less effectively positioned in the Ig6o's than it had been during earlier periods.

\section{A. The Use of the Budget Power}

The Budget Bureau always exercised a virtual monopoly as the central budget review agency of the federal government. It seldom possessed exclusive use of that power because from time to time other presidental staffs intervened in the budget process, sometimes even overriding the judgments and procedures of the Bureau. Nevertheless, central budget review for the President was the number one aim in the creation of the Bureau and this function always was the core of its power. Yet the function was put to different uses by the nine Presidents served by the Bureau. While no President can afford to ignore or withdraw from the budget process, budgeting has become less useful to the President than it once was. In fact, the budget process tends to operate as a constraint on presidential power rather than as an opportunity for the development and assertion of presidential policies and priorities. Accordingly, contemporary Presidents may find it to their advantage to spend comparatively little time on budget matters and to insulate themselves from the process. In preparation of his $197 \mathrm{r}$ budget, President Nixon is reported to have invested approximately 40 hours and to have been displeased by what he regarded as an unproductive use of so much of his time. Among the changes wrought by the establishment of the Office of Management and Budget is the interposition of an additional layer between the President and the budget director and two new layers between the examinations divisions and the White House. These moves attest to the decline of the budget process as an instrument of presidential power and, concomitantly, a decline in the status of the agency which superintends that process. 
From the start, the budget process was operated in a way that restricted its utility for presidential policy making. The I92I Budget and Accounting Act did not change the manner in which agencies prepared their budgets but interposed the President and the Budget Bureau between the spending agencies and congressional committees. Just as they had for more than a century, agencies continued to prepare their estimates with freedom to ask for whatever they wanted, and without much guidance or constraint from the President. The President entered the budget process after the agencies had formulated their requests, and he was authorized to make his own spending recommendations to Congress. This division of budgetary labors gave policy initiative to the agencies and spending control to the President. As long as he was actively involved as a budget cutter and was willing to abjure a policy development role, the President was well served by a budget process and a Bureau which functioned almost exclusively as agents of spending control. This course of action was precisely the one taken by the Budget Bureau in its inaugural year under Charles Dawes and was the dominant role of the Bureau until the New Deal effected radical changes in federal programs and expenditures. Dawes dedicated the Bureau to the "routine business" of economy and efficiency, involving his small staff in the minutiae of budget execution and separating the budget routines from the policy operations of the government. Dawes understood that his new organization would succeed only if it secured presidential support by achieving its presidential mission. Without the President, the Budget Bureau "would be as dead as a locomotive without water and coal." In an era when economy and efficiency were the bywords of American politics, Dawes succeeded in winning presidential support by producing immediate and deep cuts in federal spending, thereby demonstrating the utility and potency of the new budget process. Perhaps from a contemporary perspective it is difficult to comprehend a President so heavily engaged in economy and efficiency, but the I920's were different times, and perforce, so too were the uses to which budgeting was put. However, by structuring the budget process in a way that confined the President and the Bureau to a budget-cutting role, Dawes and his successors left a legacy which to this day constrains the policy-making usefulness of the budget process.

The coming of the New Deal rendered budget-cutting secondary, and in some ways contrary, to presidential interests. At a time that the President was promoting expansionist programs, continued use of the budget process to hold down spending would have hindered the President's policy goals. Accordingly, much of the control apparatus built during the rgzo's (including the Business Organization of the Government, the Coordinating Service, and the Bureau of Efficiency) fell into disuse and was dismantled. The Bureau withdrew from detailed budget execution, so that "except for apportionment, budget is regarded as a responsibility

\footnotetext{
${ }^{\circ}$ C. Dawes, The First Year of the Budget of the Untred States, at $x$ (1923).
} 
of departmental and agency management." The apportionment process was turned into a mechanism for the assertion of presidential policy preferences on particular matters. By impounding funds appropriated contrary to his wishes, the Bureau enabled the President to partly offset his lack of an item veto and to contravene congressional intent and bureaucratic pressures.

The abandonment of close spending control did not spell the depreciation of the Bureau as a presidential institution because it was coupled with the acquisition of new assignments, in the area of legislative clearance and administrative management, which were vital to the President and over which the Bureau held a virtual monopoly. But though these new roles enabled the Bureau to enhance its position in the Executive Office, they did not reverse the decline in the usefulness of budgeting for the President. As we have explained, except in special circumstances, the President no longer operates as the controller of agency spending. Annual increases in federal expenditures no longer are regarded as signs of impotence or inefficiency, and no stigma attaches to a President who recommends budget totals appreciably higher than the previous year's. Quite the contrary, since the New Deal a rising budget has been interpreted as evidence of vigorous presidential leadership in national affairs and of the entrance of the federal government into new responsibilities. Each year the President's budget points to spending increases as indications of the goals and accomplishments of his administration. With some exceptions (such as President Johnson's first budget for fiscal r965), recent Presidents have centered their attention on budget totals and on a small number of program initiatives, leaving the details of the budget, including many important policy questions, to be worked out by the Budget Bureau. This limited presidential involvement has been facilitated by the enlarged role of the budget as an instrument of fiscal policy. Inasmuch as fiscal policy concerns budget aggregates, a President who gives primacy to this approach has grounds for making his overall budget decisions somewhat independently of the particular program choices and costs that constitute his budget. Thus in switching to the "full employment" definition of budgetary balance for his 1972 budget, President Nixon made some early decisions on the acceptable range of budget aggregates and he subsequently gives less attention than in the preceding year to the details of particular programs.

The withdrawal of the President from detailed superintendence of the budget process has coincided with the entrenchment of the incremental rules and strategies described by Aaron Wildavsky in The Politics of the Budgetary Process. ${ }^{7}$ By means of incrementalism, budgeting has been bent to a purpose that is virtually the opposite of what was intended originally. Rather than operating as a presidential weapon against agency spending pressures, the budget process enables agencies to mobilize support for their activities and expenditures and to push for an ex-

\footnotetext{
' J. Burkhead, Government Budgeting 354 (I956).

7A. Wildavsky, The Politics of the Budgetary Process (I964).
} 
panded base. Under incremental rules, the spending base-what agencies were authorized to do and spend last year-escapes rigorous presidential or Budget Bureau scrutiny, with the consequence that the President is locked into the spending commitments made in the past, and he possesses effective control over only a small fraction of the budget. When he tries to cut the base-to eliminate the tea tasters or to reduce impacted school aid-the President often is unable to overcome congression or bureaucratic opposition. Most Presidents, therefore, have been content to accept the base (which grows from year to year) as uncontrollable. This means that a President who wants to redirect federal programs and priorities finds himself constrained by the many mandatories and pressures written into the budget, and he is tempted to work through nonbudgetary channels to achieve his program objectives. Faced with a budget that is an agglomeration of his predecessors' legacies, a President may decide to get through legislation what he cannot buy through his budget. That is, he may propose program starts with low buy-in costs as a means of evading the constraints of the budget, thereby assuring that the budget will continue to remain beyond his control in future years.

Thus the implications of incrementalism for relations between the President and the Budget Bureau were far reaching. First, the Bureau was the bearer of bad news, informing the President that most of his opportunities had been mortgaged by prior commitments or by agency spending demands. It is not surprising for the President, under such circumstances, to keep some distance between himself and his budget process. Second, the President may strive to circumvent the budget process and its constraints through his legislative program. As we will explain later, he probably will draw on the staff and skills of the Budget Bureau, but not on the Bureau as an institution. Third, the President will concentrate his interests on the spending aggregates and on select policy issues, but he will not be much concerned with the budget process or with the routines of the Bureau.

The Budget Bureau never abandoned completely its budget-cutting ethic, though it generally abided by the norms of incrementalism and only feebly cut into the spending base. Increasingly, Bureau personnel became involved in presidential policy formulation, sometimes on detail to special task forces, occasionally (as in the genesis of the antipoverty program) as forceful advocates for particular approaches. But this left the Bureau with a serious ambivalence concerning its budget role: no longer fully a budget cutter, but not quite a program planner, the budgeter had to operate under conflicting norms and pressures. PPBS and the reorganization plan which terminated the Bureau represented somewhat divergent ways of coping with this ambivalence: the former would have united budgeting and presidential program planning; the latter established separate institutions for budgeting and programming. Both approaches recognized that budgeting had lost its pivotal position for the presidency. 
B. Legislative Clearance and Program Development

The second central function performed by the Bureau was program planning for the President, through the legislative clearance process and by means of ad hoc arrangements. Richard Neustadt has described how legislative clearance began modestly in the Harding Administration, but through a series of accretions became a leading mechanism for shaping the President's program. Neustadt suggests that this process gravitated to the Budget Bureau because "there are no other workflows so compelling of decision on a constantly recurrent basis-except, of course, those in the budget process." ${ }^{8}$ Neustadt's account ends during the Eisenhower years when White House staffs were small by comparison with their present size, and the Bureau was operating without a potent rival. In later years, this position was attenuated by the growth of an independent White House capability to which the Bureau became subservient.

Legislative clearance was inaugurated in the Bureau's first year simply as a means of buttressing its new spending controls. The initial regulations dealt only with legislative proposals "the effect of which would be to create a charge upon the public treasury or commit the Government to obligations which later require appropriations to meet them." Until the New Deal, legislative clearance was limited to this negative use, to deter agencies from securing via legislation what they could not obtain through budgetary channels. But just as it impelled a redirection of the budget process, the New Deal broadened the scope of legislative clearance by eliminating the distinction between fiscal and nonfiscal matters and prescribing that all legislative proposals must be cleared through the Budget Bureau to determine whether they are in accord with the President's program. Significantly, the clearance machinery laid virtually dormant during the first two years of Roosevelt's Administration; "the most important legislative proposals were not submitted either to the Budget Bureau or to the National Emergency Council."10 To have required that all legislation be cleared through the Budget Bureau undoubtedly would have slowed the flow of program proposals to Congress.

In revitalizing and expanding the clearance process, Roosevelt was reacting to the increasingly independent and uncoordinated legislative initiatives taken by the departments. Roosevelt viewed central clearance as a means of enabling his agents in the Budget Bureau to keep track of, and oppose or thwart when necessary, the many proposals sent to Congress by the departments. Thus even as he amplified its scope, Roosevelt retained the negative orientation of the clearance process. The President "intended to protect not just his budget, but his prerogatives, his freedom of action, and his choice of policies, in an era of fast-growing govern-

\footnotetext{
${ }^{8}$ Neustadt, Presidency and Legislation; Planning the President's Program, 34 Ar. PoL. Scr. Rev. I02I (1955).

- United States Buread of the Budget, Circular 49 (Dec. ig, ig2i).

${ }^{20}$ Pearson, supra note 2, at 139 . The National Emergency Council was an interagency, Cabinetlevel group that functioned during the early years of the New Deal and was abolished in I939.
} 
ment and of determined presidential leadership."11 In fact, much of the clearance effort was devoted to enrolled bills awaiting presidential action.

The clearance process underwent further expansion during the Truman presidency when it was converted into a mechanism for the preparation of the President's legislative program. "The emphasis of central clearance had been negative; it was to be made positive. It had interpreted policies and programs where it found them; it was to help create them. It has relied on Bureau staff resources; it was to draw instead on the expanding Executive Office as a whole."12 This enlarged process involved both the solicitation of departmental legislative proposals in conjunction with the annual call for estimates and the preparation of a comprehensive program for presentation to Congress. Legislative clearance was the the routinization of the President's leadership in program formulation, a role which was legitimized by the New Deal and retained (albeit less vigorously) by President Eisenhower when he returned the White House to the Republicans in 1952.

While the clearance process was continued in the 1960 's, its scope and importance diminished significantly. The role of the Budget Bureau shrunk in consequence to the emergence of separate legislative liaison and policy staffs in the White House, and the highly routinized clearance machinery was shunted to a subordinate position. On the most important matters, the Bureau's legislative reference unit was bypassed altogether, drawn in as only one of several participants but without a lead role, or put to work under the direction of White House aides. In short, although the forms of legislative clearance remained unchanged, and Bureau personnel continued to be active in policy development, the initiative passed from the Bureau to the White House.

In Truman's time, the Bureau gained eminence in program planning and central clearance because it had no peer as the supplier of data and expertise and was eager to work in tandem with a small White House staff. The central wartime staff (the Office of War Mobilization and Reconversion) had been disbanded, the President was striving to build a record in the face of determined congressional opposition, and Budget Director James Webb liberally offered his legislative reference staff for presidential use, breaking "precedent by making his subordinates available to White House aides, on their terms, for their purposes."13 In effect, the legislative reference group was co-opted by the White House, though it retained its official identity within the Bureau. Under President Eisenhower, the Bureau continued to maintain its pivotal position because it satisfied two needs that confronted the new inexperienced administration: "the need for facts about the past to help project decisions for the future, and the need for caution in commitments

\footnotetext{
${ }^{11}$ Neustadt, Presidency and Legislation, The Growth of Central Clearance, 38 AM. PoL. Scr. Rev. 650 (x954).

${ }^{12} \mathrm{Id}$. at 660 .

${ }^{18} I d$.
} 
until homework has been done."14 But in retaining its presidential role, "the Budget's clearance operations were dependent, now more than ever, on guidance from the President and access to him, by and through his White House aides."15

The clearance and program planning system which was elaborated during the I940's and I950's was downgraded during the I960's. President Kennedy dismantled much of the coordination machinery established by his predecessor and he preferred to work with White House intimates on major policy issues, drawing the staff of the Bureau into the informal process as the need arose. Kennedy had his Sorensen, Johnson his Califano, and Nixon his Ehrlichman to oversee and pull together the presidential policy-making apparatus. On the basis of interviews in Washington, Robert S. Gilmour reports "the opinion is widespread that the White House has taken over from Management and Budget on legislative matters of 'any real importance." "16 When President Johnson's 1967 task force on government organization examined the inadequacies of the President's policy-making institutions, it proposed the creation of a new unit divorced from the legislative reference operations. And, of course, the I970 reorganization of the Executive Office provided for a Domestic Council as the President's policy staff functioning independently of the legislative reference machinery.

Undoubtedly, the decline of the routinized clearance process was due in part to the personal styles of Presidents Kennedy and Johnson and to their preferences for working closely and informally through White House assistants. Once the new policy staffs were installed in the White House, the Bureau lost its monopoly and the leverage which it provided. Compared to the President's own men, it was difficult for the Bureau to speak authoritatively in the name of the President or to respond swiftly to the President's policy directives. But the decline in the Bureau's program planning role also was due to inherent limitations in the central clearance process. As it became entrenched in its routines, legislative clearance came to be the procedure for the disposition of the thousands of legislative items not commanding presidential attention, with the White House handling the major items and articulating the President's priorities. The programs which went through the clearance machinery were departmental programs, not the President's own initiatives. Despite its enlarged scope, legislative clearance always had been more appropriate for overseeing the departments than for formulating new programs, and it never quite outgrew the negative orientation with which it had been originated. Thus, the clearance process had not been a suitable instrument for recent Presidents who wanted to carve their own program goals independent of the departments. Moreover, the clearance process in the Bureau never was able to cope with bursts of legislative and program activity. The clearance staff always has been

\footnotetext{
14 Id.

${ }^{15}$ Id. at 665 .

${ }^{10}$ Robert S. Gilmour, Central Legislative Clearance: A Revised Perspective, 31 PuB. AD. Rev. ${ }_{5} 6$ (x97I).
} 
too small-about a dozen professionals-to monitor the congressional hopper and also formulate policies for the President.

Even during the heyday of legislative clearance, there had been some questioning of the Bureau's capability to function as the President's policy arm. Arthur Maass in a I953 article pointed to potential conflicts between the staff's and the client's perspectives and he called for the establishment of a new presidential unit that would not be bound to the traditions and limitations of the Bureau. While this proposal was not realized until 1970, it received informal recognition in buildup of the White House staff in the I960's. The I947 precedent of detailing Bureau personnel to White House assignments became the standard operating procedure of the I960's. However, the result was the demoralization, and possibly also the debilitation, of the Bureau as an institution. By the close of the decade, it was generally recognized by observers of the presidency that the central policy machinery was in need of repair; frenetic improvisations were no substitute for careful policy research and follow-through on program initiatives.

\section{Administrative Management}

Leadership in administrative improvement was conferred upon the Bureau by section 209 of the Budget and Accounting Act of 1921, but it was only with the issuance of Executive Order 8248 in I939 and the rapid expansion of its staff that the Bureau actively assumed this role. ${ }^{17}$ A Division of Administrative Management was formed, and it attracted some of the best young talent in public administration, including a number of persons who were to become postwar leaders in American political science. In I943, a field service was added to carry the ideology and methods of administrative reform to federal operations across the country. At its peak, Administrative Management was the second largest unit in the Bureau, and it functioned as an in-house consulting service for the federal bureaucracy. The Division conducted hundreds of administrative surveys and it aided the War Department to convert from a peacetime to a wartime footing. According to contemporary accounts, the Bureau's work in administrative management was perhaps the main factor in the Bureau's prominence during its first years in the Executive Office. ${ }^{18}$

The Bureau came to leadership in administrative management with a big headstart over all other presidential agencies. "Of the entire President's office, only the Budget Bureau had any sort of detailed knowledge of federal organiza-

\footnotetext{
${ }^{18}$ Executive Order 8248 directed the Budget Bureau "to keep the President informed of the progress of activities by agencies of the Government with respect to work proposed, work actually initiated, and work completed, together with the relative timing of work between the several agencies of the Government; all to the end that the work programs of the several agencies of the executive branch of the Government may be coordinated and that the monies appropriated by the Congress may be expended in the most economical manner possible to prevent overlapping and duplication of effort." Exec. Order No. 8248, 3 C.F.R. 217 (Supp. 1939).

${ }^{18}$ See Marx, supra note 2, at 887-92.
} 
tion."19 The Bureau also enjoyed a favored position vis-à-vis most federal departments which (with some notable exceptions such as Agriculture) did not yet possess management staffs of their own and were willing to turn to the Bureau for advice and guidance. The entrance of the Bureau into administrative management came at a most opportune time. The program development phase of the New Deal had ended and left in its wake a sprawl of new and vastly expanded federal agencies. There was a need for administrative improvement comparable to the program innovations that had been made. By I937, Roosevelt sensed that the task at hand was to make the new programs work, and to work well, and to provide presidential leadership in the management of the federal establishment. He set up the President's Committee on Administrative Management and its recommendations led to the creation of the Executive Office and the expanded role of the Budget Bureau. "The administrative research functions," it reported, "are practically undeveloped; it is in this respect that the Bureau has missed its greatest opportunity."20 The new emphasis on administrative management was in accord with the orientation of Budget Director Harold Smith who frequently spoke and wrote of the Bureau from a management point of view. ${ }^{21}$ The rise of administrative management also was abetted by the release of the budget process from the control orientation which had prevailed earlier and by the ability of the Bureau to multiply its staff (from 45 when the President's Committee reported to 564 only seven years later). Finally, the rise of administrative management came at a time when public administration was at a peak in the United States, and the Bureau effectively cashed in on this prominence.

The decline of administrative management occurred over a period of years and was not the consequence of any particular event. After World War II, administrative management was downgraded in the Bureau, and the authorized strength of this Division was cut sharply. In 1952, as part of a general reorganization of the Bureau, the Division was replaced by an Office of Management and Organization, and in the following year the field service was terminated. Increasingly, the President turned to alternative organizations, such as the two Hoover Commissions, for overall leadership in administrative reform and to handle major reorganizations, while the Bureau was consigned routine administrative matters of low presidential concern. Federal agencies began to develop their own management staffs and they had less need for the Bureau's services. In addition the growing numbers of management consulting firms were competitors to the Bureau, and most agencies apparently preferred to go outside to supplement their own resources. Of considerable relevance to the decline of administrative manage-

\footnotetext{
${ }^{10}$ Pearson, supra note 2.

${ }^{20}$ President's Compmttee on Administrattve Management, Report With Spectal Studies i6 (r937) [hereinafter cited as President's Commitee].

${ }_{21}$ A number of Mr. Smith's articles and addresses were published in H. SMath, The Management of Your GovernMeNT (I945).
} 
ment was the postwar shift in public administration from a reformist discipline beholden to the norms of efficiency and committed to the improvement of government operations to a diffuse field in search of new scientific foundations. Many public administrators came away from their wartime experiences rejecting the administrative dogmas that had been handed down to them, and disengagement from practical administrative affairs became a widespread means of accommodation to their own uncertainties. The net effect was to sever administrative management from the discipline in which it had been molded.

As the traditional concerns of administrative management receded from presidential attention, the administrative experts in the Bureau were left without a White House interest in their services. Meanwhile, the Bureau did not successfully make the transition to the new administrative problems that were reaching the President's desk. These pertained to the management of programs cutting across departmental and governmental lines. Here was an area in need of coordination for none of the provisional coordinating mechanisms set up by the President (the Office of Emergency Planning, and the Vice-President's office in the intergovernmental field; lead and convenor machinery in the interdepartmental field) were doing the job well enough. Nor was the Bureau. It was impeded by several factors: its own inability to reorient the Office of Management and Organization; Congressional rejection of attempts to re-establish a field service; the reluctance of agencies to solicit or bow to intervention by the Bureau; and the high political stakes inherent in interdepartmental and intergovernmental problem solving.

By the middle of the I 960 's, the administrative management group was, in the words of a working paper prepared for the Bureau's rg67 self-study, "A depressed area ... which has been looking too long at the same problems and has gone stale."22 The Steering Group found that the Bureau had difficulty in obtaining and retaining capable management personnel, and that "agencies have moved well ahead of the Bureau in organization and management and new developments have not come from the Bureau." The chief aim of the subsequent reorganization of the Bureau was to revitalize its capacity to deal with intergovernmental and interdepartmental problems. An Office of Executive Management was formed, oldtime management people were encouraged to leave, and new men were brought in. Creation of the Office of Management and Budget (as the name suggests) is a further effort to restore the Bureau to leadership in administrative management.

Thus, at the time of its demise, the Bureau had lost its presidential position in the three major functions it had previously acquired. Of course, many other functions had gravitated to the Bureau over the years. Of these, two warrant brief comment. Under the Federal Reports Act of I942, the Bureau had the potential

\footnotetext{
${ }^{22}$ This and all subsequent quotes that are not attributed to source are from the unpublished minutes and working papers of the Steering Group. These documents are held in the Library of the Office of Management and Budget.
} 
to become not only the clearinghouse for forms and surveys issued by federal agencies but also the overseer of the information systems operated by the agencies. The Bureau never sought to achieve this potential, and it settled for a narrow role in statistical policy that was peripheral to its broader budgetary and management functions. The second function-fiscal policy-was born in the early years of the Keynesian Revolution when the Bureau established a small fiscal analysis unit that had the potential to become one of its most vital operations. However, this potential died on the vine with the transfer of fiscal analysis to the new Council of Economic Advisors in I946.

Charged with many functions, some of which were at cross purposes and none of which commanded the highest presidential attention, the Budget Bureau became a clustering of hard-working and reasonably well-informed individuals struggling to accommodate their many assignments and diversions to the inelasticities of the clock and calendar. Individually, Bureau personnel often performed brilliantly, but the Bureau lacked a "clear sense of purpose and direction"; its staff was "not pulling together."

\section{II}

\section{The Bureau as a Presidential Institution}

Shortly after he was appointed the first budget director, Charles Dawes recorded in his diary that he had once told the President: "if I could take any office I would not want the position of Secretary of the Treasury, but that of an assistant secretary to the President."23 During his one-year stint as director, Dawes constantly kept this preferred role uppermost in his mind as he carefully laid precedents for perpetuating the Bureau as a presidential institution. Although the Bureau was lodged in the Treasury Department, Dawes fostered the myth that it operated solely "by direction of the President." Dawes' conception of the Bureau and its director were shared by President Roosevelt's Committee on Administrative Management. The Committee rejected the recommendation of A. E. Buck, its eminent consultant on budgeting, that the Bureau be made an integral portion of the Treasury Department in order that there be a single agency with full responsibility for the financial policies of the national government. The astute members of the Committee preceived that far greater than the need for fiscal coordination was the need for a presidential agency with comprehensive superintendence over federal administration. Accordingly it urged that the Bureau be restructured "to serve in various ways as the agent of the President," and that the budget director "be relieved to the greatest possible extent from the minor details of administration. He should be released for duties of maximum importance to the President."24

\footnotetext{
${ }^{38}$ C. Dawes, stipra note 5 , at 46.

24 President's CoMmtriee, supra note 20 , at I7.
} 
By the mid-rg6o's, the conception of the budget director's role held by Dawes and the President's Committee had been realized, but not their conception of the presidential mission of the Bureau. "In recent years, the director has become more and more a White House assistant," a finding which was supported by the steering group's research. Between 1962 and 1966 , the portion of the items signed by the director that went to the President nearly doubled, from twenty to thirtyeight per cent. In terms of workload, the volume of correspondence to the President shot up from 293 items in 1962 to 642 items just four years later. ${ }^{25}$ Wearing his second hat, the director pulled other Budget men into the frenzy of presidential policy-making, but this role laid bare one inadequacy of the Bureau and gave rise to another. It revealed the unpreparedness of the Bureau to serve as a presidential institution, and it barred the director from giving adequate attention to the management of his own organization.

The unpublished minutes and papers of the steering group candidly discussed the Bureau's infirmity to perform in a presidential role. The Bureau was inhibited by its traditional style, "the doctrine that the Bureau serves an abstraction called the 'Presidency' rather than individual Presidents." Many staff members resisted their intensive contacts with White House operators "as not being in keeping with the traditions and professionalism of the Bureau." The failure of the Bureau to tool up for a presidential role placed "an inordinate burden on the director. He has no institutionalized resources to which he can turn. He finds himself spending a great deal of time handling specific requests [from the White House] and in integrating the various pieces of information from inside and outside the Bureau."

The Bureau's failure to orient itself to the service of the President was due largely to its institutional status. As it became the institutionalized presidency, the Bureau became separated from the President. With a 500-man complement, the Bureau was just too large and too remote to be the President's own. It had so many things to do of middling or low presidential concern, and though he could impress Bureau men into his service for short-term projects, the President could not get the Bureau to assign its staff to full-time presidential work. William Carey who saw the White House from his position as Assistant Director of the Budget writes:

Lyndon Johnson spent the better part of a year badgering the Budget Director to assign "five of the best men you have" to drag advance information out of the agencies about impending decisions and actions ... but the Budget Bureau never came anywhere near satisfying him because its own radar system was not tuned finely enough. ${ }^{26}$

An institutionalized Bureau could serve every President with fidelity, but it

\footnotetext{
${ }^{28}$ STEERING Group, supra note 4, at 3-3, and working papers prepared for the Steering Group.

${ }^{20}$ Carey, Presidential Staffing in the Sixties and Seventies, 29 PuB. AD. REv. 453 (1969).
} 
could effectively serve only a caretaker President. It could not be quick or responsive enough for an activist President who wants to keep a tight hold over program initiatives. The Bureau had "a negative, critical style, rather than a positive, creative one"; many old-timers who had internalized the norms of spending control could not adjust to the "go-go" posture of the New Frontier and Great Society. Over a period of decades, the Bureau had become a rigidified institution, suffering from what Herbert Kaufman has termed the "natural history of organizations." The routines of budgeting and legislative clearance, to mention only the two most important ones, had been solidified by years of tradition-building and practice, and were not easily changeable. It was a labyrinthian task to make even minor modifications in the procedures for budget preparation and review, and in fact, few changes were made in this process pursuant to PPBS.

The President could not combat these ridigities through his power of appointment or by taking advantage of staff turnover within the Bureau. President Harding had made the Bureau his own by creating an entirely new organization; FDR accomplished almost the same thing by multiplying the Bureau's staff tenfold. In the I960's, an incoming President had authority to appoint a handful of the Bureau policy-leaders and by tradition most of these (the deputy director, some of the assistant directors, and the division chiefs) came up through the ranks rather than from outside. Nor could the President depend on ordinary attrition to free slots for new men. Contrary to popular impression, there was considerable immobility in the Bureau, especially in its upper ranks. Fully two-thirds of the supervisory officials had been in the Bureau sixteen years or longer, ${ }^{27}$ a statistic that suggests the diffculty of remaking the Bureau in the President's image.

The capability of the Bureau to function effectively in a presidential role was impaired by the close identification of many examiners with the agencies they were assigned to review. There are strong incentives for examiners to maintain favorable relations with their agencies; they depend on the agencies for a steady flow of data, as well as for judgments on the value of particular programs. While their contacts with White House staff are sporadic and often curt, examiners have continuing, personal contacts with their agency counterparts. The examiners are well-informed on the wants and preferences of their agencies; often they must work without specific policy guidance from the President's men. Examiners frequently hold the same agency assignments for a number of years and are called upon to review the very programs they once had a hand in formulating. Career advancement for many examiners is via transfer to agencies with which favorable relations had been forged. While outright sweetheart relations are rare, many examiners are forceful protectors of their agencies' interests. When PPBS was started, they protected the agencies against efforts by analysts to probe more rigorously into the worthwhileness of federal programs. And they regularly protected

\footnotetext{
${ }^{27}$ STEERING Group, supra note 4, at 6-4.
} 
their agencies during Director's Review (conducted by the Bureau at which final sub-presidential decisions are made) which is structured as a sort of adversary confrontation between the examinations divisions which defend their budget recommendations and the budget director who presides as the guardian of the President's interests.

The conversion of the budget director into a White House assistant and the failure of the examiners to manifest a presidential perspective engendered serious problems in the management of the Bureau. In the words of the Steering Group,

the quality and individual competence of budget directors ... has been so great that Bureau stature in the view of the President and Congress probably never has been higher. Paradoxically, the institution has suffered internally because of inattention to day-to-day management.

The cost of prolonged inattention to the management of the Bureau was manifold. Because there was no one short of the director (and his deputy) to tend to the operations of the Bureau, the staff often had to work without adequate or timely feedback and without guidance from above. The morale of the Bureau suffered, and so did its capability to respond to presidential needs. Another problem was the difficulty of effectuating changes in the Bureau without active support and direction from the top. Had the director been able to give attention to the implications of PPBS for his own agency and to the modifications that should have been made in budget practices, PPBS would have had a much better chance for success. But although the director was committed to the principles of PPBS, he was able to apply only minimal pressure on the examinations divisions, and he never took the necessary steps to tool up the Bureau for PPBS. The result was that the Bureau required more PPBS material from the departments than it could handle, and the departments readily perceived that the Bureau was not practicing what it was preaching.

Perhaps the most costly problem was the inability of the director to transfer his presidential role to the Bureau as a whole. In his service to the President, the director was divorced from his staff, and much of the Bureau's presidential work was done with only limited utilization of the staff. By giving attention to internal management, the director might have been able to harness the Bureau more effectively to a presidential mission, but that might have rendered him less available to advise the President.

The 1967 Steering Group proposed to remedy these problems by: (I) establishing a new high-level position for internal management; (2) bringing the assistant directors into managerial roles; and (3) delegating a greater portion of the workload to the divisions. The 1970 reorganization went a big step further. In effect, it severed the director of the Office of Management and Budget from the daily operations of his agency. The director is available to serve as a presidential advisor (his office is in the White House) and to draw on the resources of OMB as the need arises. He has two deputies to handle the management and budget 
components of this new conglomerate, and he does not preside at Director's Review of the Budget.

Despite the difficulties of maintaining itself as a presidential agency, the Bureau has wanted to hold on to that role. Power, status, and tradition have something to do with this obstinance, but also the conviction that the Bureau is best suited to serve the President. Thus from the report of the Steering Committee: "The Bureau is the only office to which the President and the White House Staff can turn for a composite perspective and Government-wide substantive knowledge of operating programs," and, "The Bureau is the only Executive Office which provides the White House on [sic] across-the-board familiarity with Federal programs."28 The effectiveness with which this case can be made depends on whether the President has alternatives to the Bureau. In 1967 , he did not; today he does.

\section{III}

\section{The President Gets Help}

The President has much more help than he had thirty-five years ago when the Brownlow Committee thought that he could be sufficiently served by six assistants with a passion for anonymity. Yet the President still needs help, not merely additional assistants, but new institutions to get the job done.

In is worth considering why the burdens of the President have so far outgrown the resources he already commands. The answer comes in three parts pertaining to the policy role of the President, his relations with the executive departments, and the intergovernmental character of many federal programs.

\section{A. Policy Leadership}

Over the past four decades, the role of the President in program planning has become institutionalized, but he has not acquired additional resources commensurate with this expanded responsibility. At first, he was adequately served by the Bureau's central clearance machinery, then he added staff to the White House, and in the I960's he relied on close associates and special task forces. ${ }^{29}$ In terms of legislative productivity, the ad hoc arrangements seemed to be effective, with Congress enacting record numbers of new programs in 1964 and 1965 . Paradoxically, however, the Great Society left in its wake the widespread belief that the central policy machinery of the federal government was in disrepair. The new programs had barely begun and they were already stirring a host of operational problems that pointed to deficiencies in design and execution. White House and Budget Bureau insiders perceived that they had failed to look far enough to the future or to relate their plans to the realities of program implementation. Alternatives had not been carefully examined; cost and effectiveness had not been accurate-

\footnotetext{
${ }^{28}$ Id. at $\mathrm{I}-9,3-4$.

10 See Thomas \& Wolman, The Presidency and Policy Formulation: The Task Force Device, 29 Pub. AD. REV. 459 (1969).
} 
ly calculated. Brain-storming might have been an appropriate method for gathering a bushelful of legislative proposals, but it could not substitute for thorough policy analysis. William Carey stated the problem candidly:

The Presidency is in trouble on several counts. Its policy analysis resources are shallow and improvised. Its planning capabilities are overstrained. It has no builtin facility for assessing changing social trends and revising priorities. ${ }^{30}$

In recent years, there have been countless proposals for some new presidential policy staff. In a paper prepared for President Johnson's Task Force on Government Organization, Rufus Miles called for an "Office of Policy Studies" to do the advance intelligence work for the President. The Task Force itself proposed a new program development unit within the Budget Bureau. President Nixon created a Domestic Council within the White House Office to direct program planning for the President. It is difficult to weigh the portent of the Domestic Council for the Office of Management and Budget. On paper, OMB has been cut off from the policy-making business. President Nixon's reorganization message stipulated a clear division of labor between the Council and OMB:

The Domestic Council will be primarily concerned with what we do; the office of Management and Budget will be primarily concerned with how we do it and how well we do it. ${ }^{31}$

If the words mean what they say, the President declared that the successor to the Bureau of the Budget could not overcome the limitations on a policy role that had beset the Bureau, and he therefore had to seek relief in an entirely new body.

Immediately after the reorganization was cleared through (or more accurately, not vetoed by) Congress, journalists began to weave speculations centering around the likelihood that John Ehrlichman would become the czar of federal domestic policy, assuming a position comparable to Henry Kissinger's in the national security field. But the appointment of George Schultz as director of the Office of Management and Budget altered the prospects substantially. Ehrlichman's Domestic Council has not grown to its predicted staff size and Schultz seems to be at least his coequal in matters of presidential policy making. Schultz, however, has disengaged himself from the daily operations of OMB. Though he had the final say on most budget appeals from the agencies, it is too early to ascertain whether the rank he has achieved in the presidential firmament will extend to his underlings in Management and Budget. It is possible that if Schultz gains in White House stature, the bearers of the Budget Bureau's tradition will suffer still further decline.

\section{B. Operational Leadership}

The second problem area for the President has been program coordination. In

\footnotetext{
${ }^{30}$ Carey, supra note 26 , at 457 .

${ }^{31}$ Reorganization Message of President Richard Nixon to Congress, Mar. 12, 1970 [hereinafter referred to as Reorganization Message].
} 
recent times, the job of the President grew so burdensome because he could not-or did not want to-rely on his departments. Operational matters which might have been settled at departmental levels were taken over by White House intervenors who were impatient for results and distrusted the slow-moving bureaucracy. Two reasons can be offered for the intervention of White House men in what otherwise might have been handled by the departments themselves. First, the federal government was faced with an increasing amount of interdepartmental business. The simple matter of placing a single-stop service center in a neighborhood involved the participation of three or more federal agencies. Second, in the eyes of White House operators, the departments could not be trusted to do the job themselves. The head of a department was beholden to his own bureaucracy and could not function as a loyal agent of the President. The authors of a Ig60 study put it this way: "Operations are too important to be left entirely to the executive agencies."32

The notion that the agencies cannot be trusted is not shared by many who have seen the government from a departmental perspective. Robert Wood who frequently felt the heavy hand of Budget Bureau and White House intervention during his years near and at the top of HUD points to problems created by an unwillingness to let the agencies do the job: "Decisions tend to be reviewed and reviewed; and operational delays increase accordingly. ... Operational matters flow to the top-as central staffs become engrossed in subduing outlying bureaucracies-and policy-making emerges at the bottom."33 Wood proposes to relieve the presidency of its unnecessary burden by restoring department heads to positions of operational leadership in their respective jurisdictions. $\mathrm{He}$ argues that secretaries could be the President's men if only they were not hamstrung by other men who claim exclusive right to speak in the name of the President. Wood foresees department heads modeled along the McNamara pattern. The stronger they are allowed to become, the more they will be independent of their own bureaucracies, and the more capable therefore to serve the President.

Wood's version of departmental leadership is embodied in one aspect of the I970 reorganization, but rejected in two others. The Domestic Council is a Cabinet-level body capable of representing the views of the departments to the President and of superintending the execution of presidential policy. This feature of the Domestic Council was highlighted by President Nixon in his reorganization message. The President took the position that establishment of the Council would mean more delegation of authority to the departments. The Domestic Council "will provide a structure through which departmental initiatives can be more fully considered, and expert advice from the departments and agencies more fully utilized."34

\footnotetext{
${ }^{33}$ J. Coffey \& V. Rock, The Presidentiat Staff 77 (ig60).

${ }^{83}$ Wood, When Government Works, The Public INTEREst, Winter, I970, 39, 42.

34 Reorganization Message, stipra note $3 \mathrm{I}$.
} 
There are other features to the reorganization plan, however, that portend continuing intervention. First, the Domestic Council can go the way of the National Security Council and supersede the departments in their own spheres of operations. Thus far, this has not happened, partly because Ehrlichman has not built up his staff to the large size anticipated at the time of reorganization. But the potential is there for the President to seize should he become dissatisfied with the operational performance of the departments. Second, the Office of Management and Budget has been given an expanded mandate to operate as program coordinator. Here, too, additional staff is a prerequisite for full assumption of the power, but there are preliminary indications that $O M B$ men have increased their intervention in departmental affairs.

\section{Intergovernmental Leadership}

A third presidential burden derives from the growth of the federal role in intergovernmental affairs. The legacy of the Great Society was several hundred additional grant-in-aid programs, and the attendant difficulties of meshing together the disjointed activities of Washington, the states, and the local governments. The President has been drawn into the intergovernmental thicket for the same reason that he has become involved in interdepartmental matters; no single department has full jurisdiction and the President cannot rely on the departments for effective program delivery. An additional factor operates in the intergovernmental sphere; the President must deal with political leaders who are not always willing to accept the decisions of the President's administrative subordinates in the executive departments.

Unless there is a massive scaling down of federal grants programs or a shift to unrestricted grants, the prospects are for an escalation of presidential attention to the relations between federal agencies and inferior political jurisdictions. Both the Domestic Council and the Office of Management and Budget have stand-by capability for intervention in particular instances when the President wishes to assert his presence and for protracted monitoring of stubborn intergovernmental issues. We can expect "flying feds" to play trouble-shooting roles in behalf of the President and to overleap departments in the negotiation of intergovernmental bargains.

\section{IV}

\section{Aund Lang Syne}

The Budget Bureau that was is not the Office of Management and Budget that will be. OMB will not be able to match its predecessor's position because it does not possess the monopoly held by the Budget Bureau over key presidential functions. The Domestic Council, however varied its experience will be under different Presidents, will be a rival of Management and Budget for all of the great func- 
tions once housed in the Bureau. However, this does not mean that OMB should be written off as a major instrument of the Presidency. To be sure, the Bureau was downgraded by the I970 reorganization, and the budget component of OMB was diminished in relation to the management work. But Management and Budget still will possess the longest institutional memory in the President's office and all future Presidents will rely on it for a variety of important chores.

To future historians, the Budget Bureau will have been another chapter in the story of the presidency. But perhaps we should bid farewell to the Bureau with the words of William Carey:

If this is to be the year of lighting for the Domestic Council, it ought not be the year of eclipse for the Bureau of the Budget, because we will not see its like again. ${ }^{35}$

\footnotetext{
${ }^{25}$ Carey, Reorganization Plan No. 2, 30 PUB. Ad. REv. 634 (1970).
} 